\title{
Conditions of Corruptive Behavior - the Example of Poland and Ukraine
}

\author{
Teresa PIECUCH, Marzena JANKOWSKA-MIHUŁOWICZ and Katarzyna CHUDY- \\ LASKOWSKA $^{1}$ \\ Rzeszow University of Technology, Rzeszow, Poland; tpiecuch@prz.edu.pl; kacha877@prz.edu.pl; \\ mjanko@prz.edu.pl \\ * Correspondence: e-mail_tpiecuch@prz.edu.pl
}

\begin{abstract}
Corruption is not a new phenomenon. It is timeless, common, universal. It is not only an economic or moral, but also a cultural problem occurring in everyday interpersonal relations in modern society. There are many reasons for corruption. They should be sought in morality, culture and customs - in politics, economic and sociological factors. Corruption is fundamentally negative. It is often viewed as a social disease that disrupts the functioning of individuals, societies, entire economies. The subject of the study is an analysis of corruption behavior determinants. It draws attention to their specificity, causes and negative consequences for various entities - individuals, enterprises and economies. Theoretical considerations in this area were supported by the authors' own research that was carried out in 2018, using a survey method in Poland and Ukraine. In the research participated 337 people. A comparative analysis of the propensity to corruption among Polish and Ukrainian respondents was made. A number of conclusions and recommendations were formulated regarding the analyzed aspects.
\end{abstract}

Keywords: corruption; corruptional behavior; corruption in Poland; corruption in Ukraine

JEL Classification: D73; E26

\section{Introduction}

Corruption is a permanent although imperfect element of social and political life (Jakubowski 2016). It is included in the group of so-called paradoxical social phenomena, due to the contradictory feelings and emotions that it triggers (Walczak 2016). It can occur not only within public, private and nongovernmental sectors but also between them. It most often takes place in the state and local government administration; health care; education and higher education; customs and tax administration; institutions implementing EU programs; law enforcement agencies; judiciary system; economic sector (Mapa korupcji w Polsce... 2010). Corruption-related relations can be established between individuals representing particular entities operating within the sectors and /or between them (Jak zwalczyć korupcję... 2010). Corruption can acquire local, regional, national or even international character. Bribery acts can be performed by renowned businessmen, big or small companies, as well as ordinary people wishing to settle their everyday matters (Lampart 2015).

In order to examine the citizens' attitude towards the issue of corruption, own research has been carried out in Poland and Ukraine. The choice of these two countries is justified by the attempt to explain such meaningful discrepancies in corruptive behaviour despite numerous similarities between Poland and Ukraine (direct neighbourhood, former socialist system experience, similar language, culture, traditions). Poland is a country where the problem in question is far less significant, whereas in Ukraine corruption is almost common, often it is hardly possible to deal with any official matter without paying a bribe. There is social consent observed for both giving and receiving bribes. The research was carried out in March 2018 among 337 respondents - 164 Ukrainians and 173 Poles. This work encompasses theoretical elaboration on the phenomenon of corruption, its specificity, consequences, the most important conclusions and recommendations resulting from the conducted research. 


\section{Corruption Specificity}

Corruption constitutes a social pathology, i.e. the behaviour of an institution or a part of social system that conflicts with the world views and the generally accepted system of values in a given community. This act is committed by anyone who, out of one's own direct or indirect interests, violates the rules which they themselves are responsible for. It is an act during which the person in charge of goods distribution in the social system violates the distribution in favour of someone for which they receive or expect gratification (Szwejkowski 2013). It is also using power for your own private purposes (Budsaratragoon, Jitmaneeroj 2018).

The corruption features include, among others: universality (it occurs on a large scale, in various areas, in almost every aspect of social life), entropy (i.e. the phenomenon spreading quickly and becoming more popular), interactionism (the participation of two entities - the "recipient" and "donor" is required for the corruption to occur), the confidentiality or secrecy of benefit exchange (Fleszar 2014).

The corruption is commonly associated with offering and accepting bribes - from the practical point of view bribery is the most popular corruption form. On the other hand, it is less often related to other forms, such as: bribery, venality, influence peddling, using one's favourable position to achieve private, family or friend-related objectives, nepotism, embezzlement, and dishonest mediation (Lampart 2015). However, regardless of the form it is defined as a complex scheme of cooperation during which either a public or private good is claimed.

The scheme comprises (Jakubowski 2016):

- corrupting party - along with their official position (professional, social), owned resources and expected benefits;

- corrupt party - it refers to the business partner of the corrupting proposal, their competitive edge towards the bidder, possessed public or private goods along with their value;

- transaction beneficiary - they directly or indirectly gain tangible benefits as a result of corruption;

- funds, involved in order for the corruption transaction to take place;

- techniques employed to execute corruption transactions and securing methods;

- frequency of corrupt agreements constituting the transaction;

- environment in which the transaction is performed.

It is commonly believed that the main reasons for corruption are the strength and wide scope of authority attributed to civil servants as well as their low salaries. The first factor contributes to creating an official's privileged position over the "petitioner", since it is up to the official whether a particular matter is considered in favour of the client, or not. What is more, a huge number of unclear regulations, bureaucracy and excessive formalism also facilitate corruption incidents. The Supreme Audit Office identifies four fundamental corruption mechanisms, i.e. irregularities that increase the risk of corruption, based on performed controls and systemic analyses. These are as follows (Hussein 2017):

- flexibility of proceedings,

- conflict of interest,

- lack of proceedings transparency,

- lack of control system or its weakness.

Corruption is fundamentally negative (Chan, Dang, Li 2019; Sumah 2018). It is referred to as a social disease destroying (Turska-Kawa 2015) not only the "soft tissue of civil society" (trust, sense of empowerment), but also disrupting the operations of fundamental organisations and institutions. However, it impinges on the lowest income individuals. The negative aspects of corruption result from the fact that it (Bil 2014; Lampart 2015):

- mostly affects individuals with the lowest income depriving them of the access to necessities;

- is often accompanied by the other forms of organised and economic crime, including money laundering;

- is often linked to direct or indirect human rights violation;

- threatens political stability and sustainable economic development;

- undermines the whole society's morale;

- contributes to building individuals' unauthorized, unjust and illegal wealth that threatens democracy and the rule of law. 
Counteracting the phenomenon of corruption is very difficult, it requires a comprehensive and multifaceted approach at the international level since, due to the globalisation process, its negative consequences are distributed among cooperating countries. Therefore, it is absolutely vital to detect and stop the international flow of unlawfully acquired funds in a more decisive, consistent and effective manner as well as strengthen the international cooperation in the fight against corruption. Only then will the poorer countries be able to combat corruption effectively and, indirectly, gain opportunity to improve in this respect. Each and every country is in charge of preventing and fighting corruption, and in order to guarantee the success in this field they must cooperate with the support of individuals and groups from outside of the public sector, such as associations, NGOs and environmental organizations (Lampart 2015).

\section{Corruption in Ukraine and Poland}

Corruption constitutes an issue in many countries around the world, but it literally plaques Ukraine. International rankings on corruption every year classify Ukraine on a very low position in this aspect. For instance, according to the Transparency International Report (a social organization, a leader in the fight against global corruption) for 2018, it held 130 position (out of 180 analysed countries) with the score of 28 points (maximum score in the ranking - 100 points, the higher score transparency, the lower score the higher corruption). In the period 2015-2018 its situation was slightly but gradually improving. The rate of growth calculated for 2018 as compared to 2015 equals $118.52 \%$, which means that the index value increased by $18.52 \%$ showing slight improvement. What is more, 2018 is the first year when Ukraine ceases to occupy the last position in the ranking among European countries - it precedes Russia that holds 135th position in 2018. Poland, on the other hand, takes the 36th position with the score of 60 points. In the corresponding period Poland's corruption index is far more favourable although it deteriorates by $4.76 \%$. According to the data in Table 1, Denmark scored the total of 88 points and was the leader in the Corruption Perceptions Index (CPI) report in 2018. It was followed by New Zealand with 87 points (the ranking leader in 2017); Finland, Sweden and Switzerland (85 points each). On the other hand, the countries with the lowest indices and positions in the ranking were: Somalia (mere 10 points out of 100), Syria, South Sudan (13 points each), Yemen and South Korea (14 points each).

Table 1. Corruption indices for selected countries.

\begin{tabular}{clcccc}
\hline No & \multicolumn{1}{c}{ Country } & $\mathbf{2 0 1 5}$ & $\mathbf{2 0 1 6}$ & $\mathbf{2 0 1 7}$ & $\mathbf{2 0 1 8}$ \\
\hline 1. & Denmark & 91 & 90 & 88 & 88 \\
2. & New Zealand & 91 & 90 & 89 & 87 \\
3. & Finland & 90 & 89 & 85 & 85 \\
4. & Sweden & 89 & 88 & 84 & 85 \\
5. & Switzerland & 86 & 86 & 85 & 85 \\
6. & Canada & 83 & 82 & 82 & 81 \\
7. & Germany & 81 & 81 & 81 & 80 \\
8. & Great Britain & 81 & 81 & 82 & 80 \\
9. & Estonia & 70 & 70 & 71 & 73 \\
10. & France & 70 & 69 & 70 & 72 \\
11. & United States of America & 76 & 74 & 75 & 71 \\
12. & Portugal & 64 & 62 & 63 & 64 \\
13. & Poland & 63 & 62 & 60 & 60 \\
14. & Czech Republic & 56 & 55 & 57 & 59 \\
15. & Lithuania & 59 & 59 & 59 & 59 \\
16. & Italy & 44 & 47 & 50 & 52 \\
17. & Slovakia & 51 & 51 & 50 & 50 \\
18. & Romania & 46 & 48 & 48 & 47 \\
19. & Bielarus & 32 & 40 & 44 & 44 \\
20. & Bulgaria & 41 & 41 & 43 & 42
\end{tabular}




\begin{tabular}{llllll} 
21. & China & 37 & 40 & 41 & 39 \\
22. & Ukraine & 27 & 29 & 30 & 32 \\
23. & Russia & 29 & 29 & 29 & 28 \\
\hline
\end{tabular}

Source: Own elaboration based on https://www.transparency.org/cpi2018, (retrieved on December 15, 2019).

Based on the considered report, the corruption in Poland is still a problem, which is illustrated by the decreasing corruption index in the period 2015-2018. However, according to the periodical public opinion survey conducted by the Public Opinion Research Centre (CBOS) some positive aspects can be identified. Positive answer to a question "Do you know anybody accepting bribes?" in 2000 was given by $29 \%$ respondents, in 2013 and 2017, respectively 16\% and 10\%. Respondents who declare knowing somebody accepting bribes are mostly highly educated, with high income, living in large cities, aged 2534 , assessing their own financial situation as poor and declaring left-wing political views. Considering the occupational groups one may note that these are usually representatives of management and senior specialists, administration specialists and office clerks, and employees in the service sector. Simultaneously, the number of respondents declaring offering bribes is also decreasing. The CBOS survey's question "Have you been forced in the last 3-4 tears to offer a bribe?" was answered in an affirmative way by $16 \%$ respondents in 1993, 20\% in 1999 (the worst result up to date) and 9\% in 2013 . The 2017 survey confirmed the falling trend with $6 \%$ respondents declaring having been made to pay a bribe in the preceding 3-4 years (CBOS nt. korupcyjnych... 2017; CBOS nt. stosunku... 2014). Thus, it proves some positive trends occurring in the phenomenon of corruption in Poland.

Because as stated above, the most common indicator of corruption CPI is defective instrument (De Maria 2008), the study also refers to the Rule of Law Index (RLI). It is prepared annually by an international organisation aiming to consolidate the idea of the rule of law around the world (the World Justice Project). In 2017 according to RLI Index, Poland was ranked on 27 position (out of 126 countries considered in the report) with the index score 0.66 points; Ukraine on 77 position with the score of 0.55 points. There are eight aspects of state affairs evaluated in the index: (1) mechanisms of government powers, (2) issue of corruption, (3) government openness, (4) fundamental human and civil rights, (5) order and security, (6) regulatory enforcement, (7) civil justice, (8) criminal justice). Taking into consideration the neighbours of Poland, the best score was obtained by the Federal Republic of Germany (0.84 points; 6th place) followed by the Czech Republic (0.73 points; 19 th place). Less favourable results were obtained by Belarus ( 0.52 points; 66th place) and Russia ( 0.47 points; 88 th place). The leaders of the RLI Law Rule Index were Scandinavian countries with the leading positions: Denmark (0.90 points), Norway (0.89 points), Finland ( 0.87 points) and Sweden ( 0.85 points). On the contrary, the lowest positions in the ranking were occupied by: Congo ( 0.33 points), Cambodia ( 0.32 points) and Venezuela (0.28 points) (WJP Rule of... 2019).

Corruption is a common worldwide phenomenon. However, in Ukraine it constitutes an extremely serious, fundamental social problem (Denisova-Schmidt, Prytula 2018). For years, the country has been occupying very distant positions in world rankings on corruption. To exemplify, one may buy any court decision in any court in exchange for a bribe. It is not rare that the court verdict is explicitly contrary to the law - all due to the corruption. One can come across a bribery pricing list for various types of "services" in Ukraine. For example: (1) \$ 100 - being granted the possibility to meet a lower-level office clerk; (2) \$ 400 - obtaining competitor's bank account statement at one of the largest Ukrainian banks; (3) $\$ 1,000$ - persuading an office clerk to deal with one's case; (4) \$3,000 - a monthly tribute charged by the General Prosecutor's Office in Kiev required to conduct the case; (5) \$ 10-30 - minor, simple cases in the court (Sikorski 2008). This has a serious adverse impact on the economy. Ukraine lacks internal investors (no capital market) and external investors quit doing business in the Ukrainian market, even though it is very receptive, mainly due to the corruption. The investments in Ukraine are usually blocked by the fear of insufficiently protected property rights as well as a corrupted judiciary system. What is more, international institutions, which could deliver sufficient investment capital, condition their support for the Ukrainian economy by clearly visible and effective anti-corruption measures, which also limits the capital inflow (Stodolak 2018). All in all, the corruption destroys the Ukrainian economy, hinders its development and negatively affects the morale of citizens. 


\section{Methodology}

The research was carried out among Polish and Ukrainian inhabitants and was based on a questionnaire which included questions on various areas related to the corruption in micro and macro - scale. The research was performed in March of 2018. For the research two statistical tests were used to allow for the indication of dependency and variations between Polish and Ukrainian group: Chi- square Independence test and the Mann- Whitney - U test.

The Chi-Square test of independence is used to determine if there is a significant relationship between two nominal (categorical) variables. The frequency of each category for one nominal variable is compared across the categories of the second nominal variable. The data can be displayed in a contingency table where each row represents a category for one variable and each column represents a category for the other variable. The null hypothesis for the test states that there is no relationship between two variables. This test could be used when: the sampling method is simple random sampling, the variables under study are each categorical and if sample data are displayed in a contingency table, the expected frequency count for each cell of the table is at least 5 .

The Mann-Whitney $U$ test can be used to investigate whether two independent samples were selected from populations having the same distribution. It is a nonparametric test of the null hypothesis that it is equally likely that a randomly selected value from one population will be less than or greater than a randomly selected value from a second population.

The significance level for a study $-\alpha$ is 0.05 . All the developed results were presented using the graphic form.

\section{Propensity for Corruption in Poland and Ukraine - Research Perspective}

In order to examine the propensity for corruption of Polish and Ukrainian citizens, own research was conducted with the use of a questionnaire. The research was performed in March 2018, there were 337 respondents - 164 from Ukraine (49\% of the entire research sample), and 173 from Poland (51\%). One shall note that the age distribution in the research sample varies according to the nationality - the Ukrainian group is dominated by respondents aged between 36 and 55 (52\%) whereas, the Polish group mainly includes younger respondents aged up to 35 years (54\%). In both groups there are more females, in Ukrainian there are more (61\%), though. Three quarters of Ukrainian respondents live in towns, whereas in Poland comparable amount of them live in towns (51\%) and villages (49\%). The respondents have higher or secondary education background, the share is very similar in groups from both countries (for secondary education in Ukraine and Poland $51 \%$ and $49 \%$, respectively; for higher education $49 \%$ and $51 \%$, respectively).

The research was aimed at examining the respondents' approach towards corruption in everyday life (in education, in healthcare, etc.). Four questions regarding "material stimulation" in these spheres and feelings associated with such activities were used. Each question was scored from 1 ("I do not agree") to 3 . In total, 16 points could be obtained in a situation that confirmed or supported corrupt activities. Thus, the higher the score the greater the propensity for corrupt behaviour and vice versa. A comparative analysis of the responses in Ukraine and Poland was held by means of the Pearson chisquare independence test. The results are presented below in the form of " $\mathrm{p}$ " probability value for each detailed question:

- Most of the respondents believe that a bribe is absolutely necessary, and "things will move only if you pay a bribe" ( $\mathrm{p}=0.08138)$; this question was answered in a similar manner, although the respondents from Ukraine agreed more often with this statement $(22 \%$ provided the answer - "I completely agree with this", in the case of Poland it was 13\%);

- In the case of children education (in general and vocational schools as well as in higher education) material stimulation of teachers (lecturers) is the right thing to do - $\mathrm{p}=0,0000$;

- The favour should be returned personally to medical doctors for their service in a material form - $\mathrm{p}=0,0000$;

- Material "stimulation" or "gratitude" is nothing extraordinary, it does not lead to unpleasant feelings (humiliation, shame or embarrassment), neither on the side of the offering party nor the accepting one $(\mathrm{p}=0.0058) ; 53 \%$ respondents from Poland and $36 \%$ from Ukraine disagreed. 
The test of independence identified significant discrepancies in the following three situations regarding: children education, medical care and attitudes towards the bribery. In Poland, the share of respondents against that kind "stimulation" is much higher than in Ukraine, especially when it comes to education and medical care, where such situations occur on regular basis. In Poland, fewer people are in favour of offering bribes to teachers, lecturers (78\% Polish respondents disagreed with such practice, $42 \%$ for Ukrainian respondents) and doctors (70\% and $31 \%$ respondents in Poland and Ukraine, respectively, were against offering bribes). According to CBOS, the problem of corruption in Poland most often occurs in the case of politicians (47\%), healthcare system (38\%), judiciary system $(32 \%)$ and local government administration (30\%). Another public opinion survey performed by the TNS Polska in 2015, medical doctor is the most corrupt Polish occupation (65\% responses) (CBOS nt. korupcyjnych... 2017).

Based on the answers provided by the respondents and regarding corruption in everyday life situations an indicator was constructed with the value ranging from 4 to 16 points. The higher the score the greater consent to corrupt behaviour. The score distribution in the case of Polish and Ukrainian respondents is presented in Figure 31. It shows that in Poland the highest number of respondents scored 5 points, while in Ukraine most often 8 points were obtained. It clearly shows that in Poland the biggest number of respondents scored 5 points and in Ukraine the score was higher and equalled 8 points.

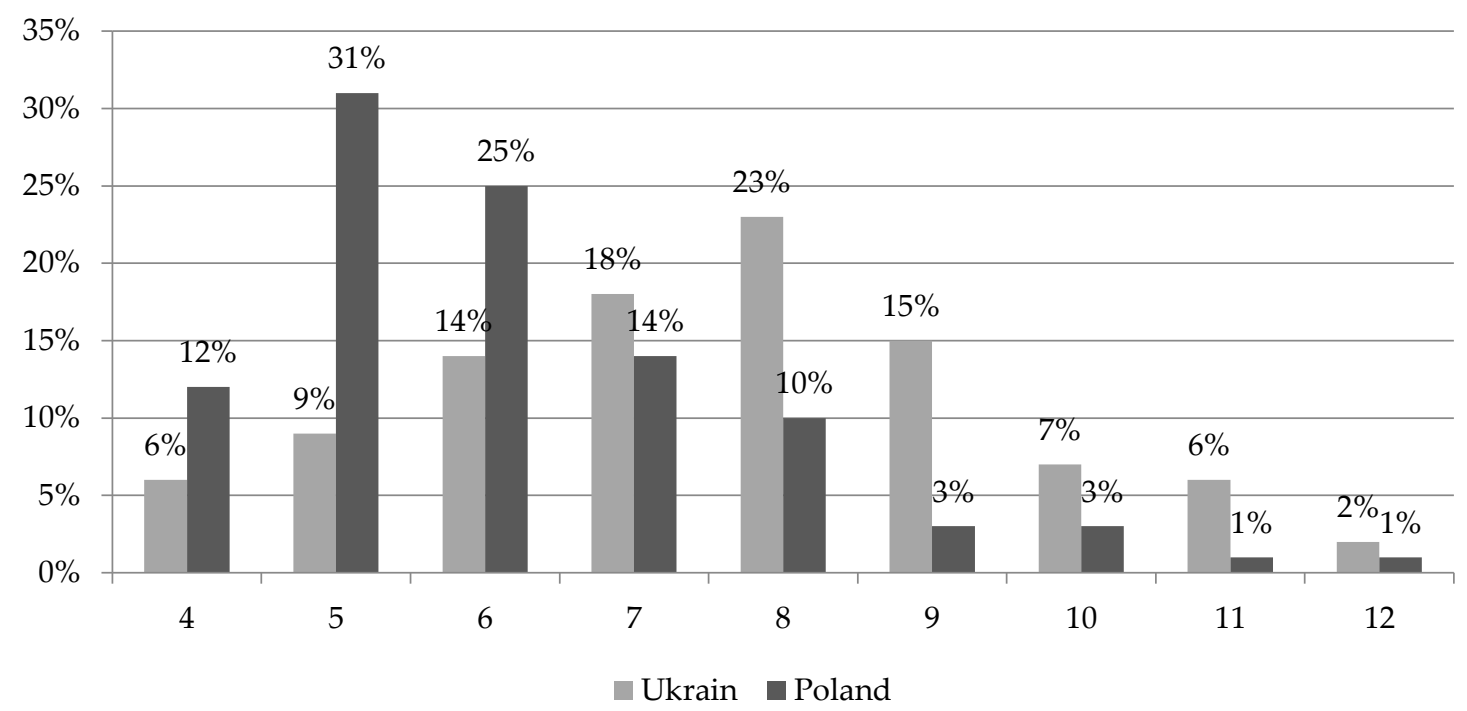

Figure 1. Score distribution regarding the study on corruption in everyday life situations in two examined research groups.

Based on the above score distribution, the U-Mann-Whitney test was implemented to verify possible differences in the amount of points scored by the respondents from the two countries. It turns out that there is a statistically significant difference in the number of points gained by the respondents in the populations, $\mathrm{p}<\alpha(\mathrm{p}=0.0000)$. This may lead to a conclusion that the public acceptance of everyday corruption in Poland is much lower (average at 6.11 points) than in Ukraine (average 7.56).

The ability to counteract corruption also matters, especially when it already constitutes a wellgrounded phenomenon. This kind of situation was also examined in this research on corruption. In order to diagnose the problem 7 questions were used regarding various aspects of corruption (in social, professional and political life). The higher the score achieved the better skills to counteract corruption. Each question was scored from 1 to 3 ("I completely agree"). Four questions were scaled quite opposite.

A comparative analysis of the research carried out in Ukraine and Poland was performed by means of the chi-square Pearson independence test. The results are given in the form of " $p$ " probability value for each of the particular questions: 
- I had to openly argue with my supervisor about working issues or my supervisor's unreasonable requirements $(\mathrm{p}=0.00131)$;

- I am afraid to refuse my supervisor so as not to harm my own business. ( $\mathrm{p}=0.96462)$;

- There are ambitious co-workers in the team who speak their mind openly without hesitation ( $p$ $=0.24074$ );

- I do not care if my vote was (is) changed during elections ( $\mathrm{p}=0.00982)$;

- If I am offered a sufficient amount of money I will vote as I am asked ( $p=0.01573)$;

- I have attended and will attend public protest demonstrations against political corruption ( $\mathrm{p}$ $=0.00000$ );

- I am not personally affected by corruption, misuse of powers is not a problem for me $(p=0.0000)$.

There are only two areas that do not differentiate the respondents - one of them is the fear of refusing one's supervisor $\mathrm{p}>\alpha(0.96426)$ and the presence of other co-workers able to speak their mind in front of their supervisor regardless of consequences $p>\alpha(p=0.24074)$. The research outcome revealed some differences in the answers regarding an open dispute with one's supervisor on working issues or unreasonable requirements. Almost $43 \%$ Polish respondents never faced such situation and $12 \%$ completely agree with the above statement. In the case of respondents from Ukraine - around 30\% do not agree with the statement but every fifth respondent experienced similar situation. Examined respondents generally have similar impressions regarding the fear of refusing a supervisor; the research showed no differences in their responses $(p>\alpha)$. Majority of the respondents partially agree with the statement (45\%) or disagree (approx. $42 \%$ ). No significant differences are noted in the case of the presence of ambitious co-workers expressing their opinions in front of supervisors - majority of them either partially or completely agree with the statement.

Taking into account the respondents' attitude towards their vote being distorted in the elections, differences between nationality groups are already statistically significant. Polish respondents pay more attention to their votes in elections $(82 \%)$. In the case of respondents from Ukraine - the same option was indicated by $67 \%$ of individuals. Surprisingly, every tenth person in Ukraine pay little attention to this issue.

Another question regarding elections also differentiates the answers in the examined research samples. For $85 \%$ Poles it is impossible to change one's vote, even if offered a sufficient amount of money. In the case of Ukrainian respondents, similar attitude is presented by $76 \%$ respondents. This means that Ukrainian voters are more flexible as far as changing their vote is concerned - $10 \%$ respondents would not hesitate to change their vote if offered a proper bribe.

Respondents were also asked about their active participation in corruption counteracting. Over half of Poles $(57 \%)$ did not participate in mass demonstrations against corruption, whereas in the group of Ukrainians only $34 \%$ did not attend such event. As many as $66 \%$ of respondents from Ukraine admitted doing so (answers "I partially agree" and "I completely agree"), so either they already participated in such protests or intend to.

Respondents taking part in the research were also asked whether they had personally faced corruption. Their answers are presented in Fig. 2. Clearly, Ukrainian respondents more often have to deal with corruption instances. 


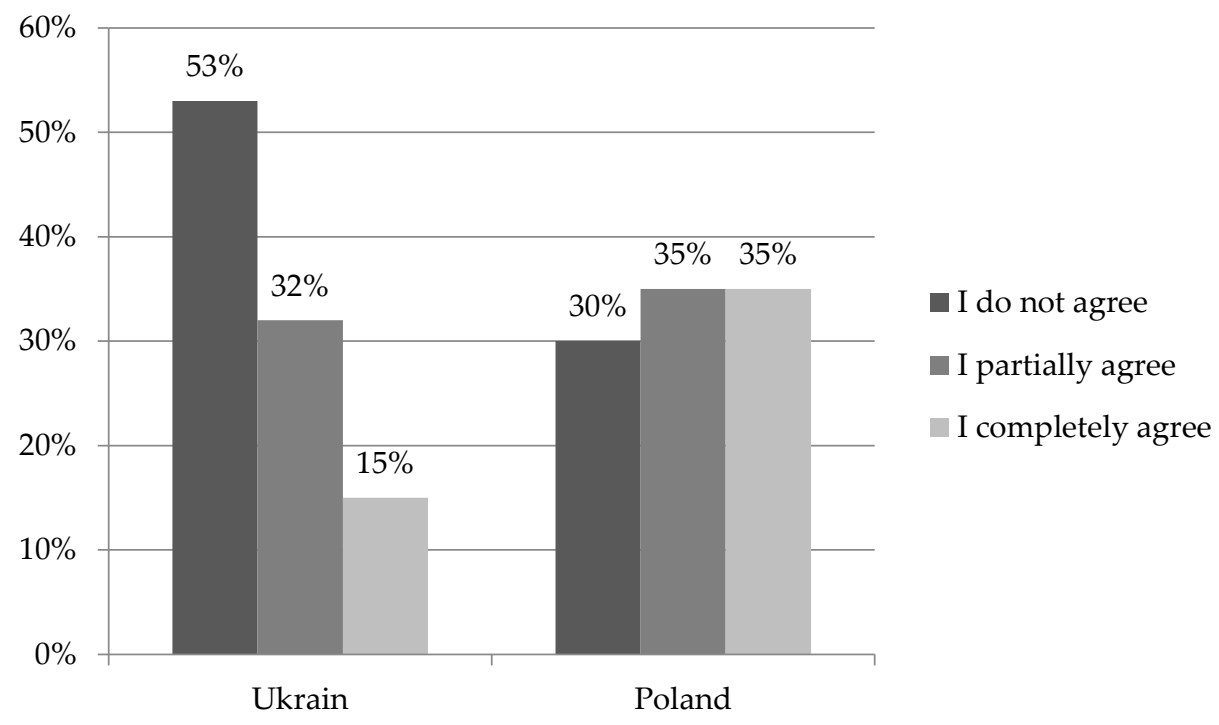

Figure 2. I am not personally affected by corruption, misuse of powers is not a problem for me.

Questions regarding the ability to counteract corruption (more precisely the sum of points collected for the questions) served as basis for creating an indicator measuring the ability to stay corruption-resistant. The indicator ranged from 7 to 21 points - the higher the indicator's value the better abilities (stronger determination) to counteract corruption. Score distribution obtained in the two examined groups is shown in Fig. 3. In Poland the biggest share of respondents scored 15 points, whereas in Ukraine - 17 points. What can be learned from the distribution is that Ukrainians are well aware of their country struggling corruption, but they show far more determination than Poles in fighting and preventing it. Less involvement of Poles in fighting corruption may be explained by the fact that they generally do not regard it a vital Polish problem.

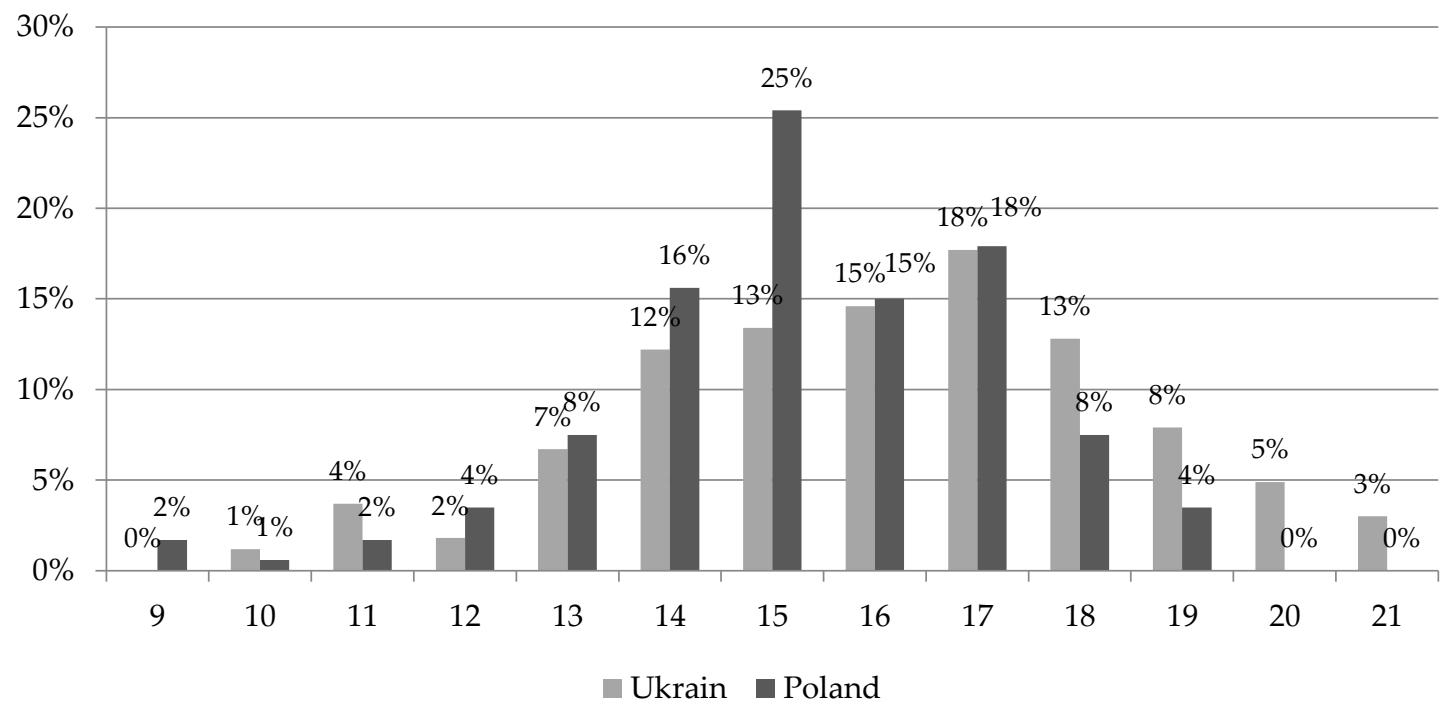

Figure 3. Score distribution in the study on the ability to fight against corruption in the two examined groups. 
By means of the U-Mann-Whitney test, differences in the level of points obtained by respondents from Poland and Ukraine were studied. The test showed a statistically significant difference in the number of points obtained in the examined populations, $p<\alpha(p=0.0006)$. In the case of Ukraine, the indicator's value is higher (16.11 points), whereas in Poland the average value equals 15.26 points. Therefore, the research proves greater skills in fighting corruption in a Ukrainian group of respondents.

\section{Discussion}

Summing up theoretical background presented in this elaboration, own research performed by the authors as well as findings provided by various institutions dealing with the issue of corruption a number of interesting conclusions can be formulated. First of all, the problem of corruption is far more significant in Ukraine, it occurs on a daily basis at both private and professional levels. In Poland the phenomenon of corruption is not as accepted as in Ukraine - its social support is much lower. The ability to resist corruption is also a factor differentiating the nationality groups. Ukrainian respondents show much more determination to fight corruption (Denisova-Schmidt, Prytula 2018). It is worth noting that in the group of Ukrainian respondents religion significantly differentiated the approach towards corruption in everyday life. Surprisingly enough, believers in Ukraine tend to accept corruption more than atheists. On the contrary, Polish respondents practicing some religion showed the least consent to corrupt behaviour. It is also interesting to note that Ukrainians do not seem to notice positive changes occurring in the phenomenon of corruption, such as attempts to reduce corruption or downward trends in the scale of corruption, which are evident according to numerous statistics and quantitative research (CBOS nt. korupcyjnych... 2017). Similar results were obtained in surveys conducted in 1998 by the Kiev International Institute of Sociology on a group of 2,600 respondents. The study showed that only a small percentage of respondents admitted that the Ukrainian government was taking effective measures to fight corruption (Cabelkova 2019). This may be explained by the massive scale of the phenomenon which actually prevents ordinary people from noticing positive but still small changes.

Due to the mainly negative character of corruption (although few researchers identify some positive aspects of corruption (Czepil 2014; Makowski 2012; Cichocki 2012), it is absolutely necessary to minimize it. The most important issue in the process of its limitation are the cultural environment, in particular social consent to this type of activity. Corruptive behaviour is deeply rooted in morality, culture, customs and habits, politics and sociological factors (Brol 2015). Fundamental causes of corruption are the very human nature, low moral costs of corruptive behaviour, weakened so called immune ethical system of a society (Szwejkowski 2013) and some space (opportunities) for corruptive decisions. Thus, corruptive behaviour is so difficult to eliminate.

It is commonly known that corruption cannot be completely eradicated, since it is a natural phenomenon (Sumah, 2018), cannot be limited by top-down regulations or strict sanctions for offering and accepting bribes. The key importance is attributed to social attitude towards this kind of behaviour and lack of social consent to the so-called soft forms of corruption (e.g. petty bribe, protectionism or intermediating non-entirely legal transactions) (Hołyst 2014), stigmatising ethically questionable activities, manifesting and spreading one's strong moral assessment of bribery.

Preventing corruption should be focused on limiting opportunities that aim to create space for corrupt behaviour (e.g. harmonise legal regulations, close gaps in law, reduce bureaucracy and discretion, improve procedures, emphasise the transparency of certain activities) by means of not only formal regulations but, most of all, at social and cultural level (suitable up-bringing, education or providing proper values); ethical behaviour should be promoted, whereas social acceptance of corruption should be eliminated (Dąbrowska-Mikuta 2013; Aktan 2015). Media may play a key role in modelling public attitude towards corruption and its perception as an essentially negative phenomenon (Cabelkova 2019). In countries such as Ukraine, where corruption scandals very rarely end up with strict court verdicts for the accused and charged, mass media can support corruption and encourage this kind of behaviour. From this perspective, people see corruption as something natural or even legal, since no penalties are imposed, especially for high-level authorities. 
Comparing situation regarding corruption in Poland and Ukraine one shall consider the development level of the countries. Corruption in Poland after the economic transformation of 1989 seemed to have been far more problematic. It constituted some kind of transformation cost (economic transformation, legal changes, lack of harmonised regulations, etc.) (Denisova-Schmidt, Prytula 2018). Along with social and economic recovery and general situation becoming more stable, the propensity for corruption decreases. For instance, in the late 1990s in highly-developed countries (including France, the Netherlands or Germany) entrepreneurs offering bribes to officials in order to obtain a significant public contract were allowed to deduct this special cost from their tax. It was only after the introduction of the OECD convention on combating bribery of foreign public officials in international business transactions of 1997 (Makowski 2012) when the situation began to change. A. Hussein claimed that consent to corruption, especially in post-communist countries, is essentially a symptom of helplessness regarding corruption and corrupt authorities (Hussein 2017). However, the most often it is rather a manifestation of the system weakness or poor management (Why corruption matters...2015), not the result of acceptance of this type of activities or other unethical behaviour.

\section{Conclusions}

Corruption is a huge economic, but also political and social problem. It affects entire societies, each individual person. It should be undoubtedly reduced. Corruption has been, is and will be present in every country, although in some it's level is very high. As An example it would be Ukraine, where corruption prevents economic development, destroys and destabilizes the functioning of the state, as well as reduces the comfort of citizens' lives. It must be strictly limited using specific system solutions. However, this requires time, it is a very difficult and lengthy process, and complex cultural changes are needed that would change the attitude of all citizens to corruption. In particular, young people should be educated, ethical behavior promoted, which, as a result, may gradually reduce corruption in the long run.

\section{References}

Aktan Coskun Can. 2015. Ethics in Gavernment: Anti-Corruption Measures. International Journal of Social Sciences and Humanity Studies: 7 (2), 63-89.

Bil Jacek. 2014. Korupcja $\mathrm{w}$ biznesie jako zagrożenie bezpieczeństwa ekonomicznego państwa. Kultura Bezpieczeństwa. Nauka-Praktyka-Refleksje: 15, 28-39.

Brol Marcin. 2015. Ekonomiczne, instytucjonalne i kulturowe uwarunkowania korupcji. Wrocław: Wydaw. UE.

Budsaratragoon Pornanong, Jitmaneeroj Boonlert. 2019. A critique on the Corruption Perceptions Index: An interdyscyplinary approach. Socio-Economic Planning Sciences: December (in press). https://doi.org/10.1016/j.seps.2019.100768.

Cabelkova Inna. 2001. Perceptions of Corruption in Ukraine: Are They Correct? CERGE-El Working Paper: 176, 1 -

58.http://citeseerx.ist.psu.edu/viewdoc/download;jsessionid=1F3831D92C18B25C9DE7B43589645FA5?doi= 10.1.1.197.7674\&rep=rep1\&type=pdf (accessed on 22 December 2019). https://dx.doi.org/10.2139/ssrn.288726.

CBOS nt. korupcyjnych doświadczeń Polaków. 2017. Available online: 27.www.antykorupcja.gov.pl/ak/analizyi-raporty/badania-opinii/12639,CBOS-nt-korupcyjnych-doswiadczen-Polakow.html (accessed on 18 December 2019).

CBOS nt. stosunku Polaków do łapowictwa. 2014. Available online: https://antykorupcja.gov.pl/ak/analizy-iraporty/badania-opinii/10199,CBOS-nt-stosunku-Polakow-do-lapownictwa.html (accessed on 18 December 2019).

Centralne Biuro Antykorupcyjne. 2010. Mapa korupcji w Polsce. Stan korupcji w Polsce na podstawie danych statystycznych przekazanych przez służby i organy państwowe za lata 2004-2009. Available online: https://www.cba.gov.pl/ftp/zdjecia/Mapa_korupcji.pdf (accessed on 18 December 2019).

Chan S. Kenneth, Dang Q. T. Vinh, Li Tingting. 2019. The evaluation of corruption and development in transitional economies: Evidence from China. Economic Modelling: 83, 346-363. https://doi.org/10.1016/j.econmod.2019.09.001. 
Cichocki Stanisław. 2012. Korupcja jako problem ekonomiczny. In Mapa korupcji. Stan przedsiębiorczości korupcyjnej w Polsce w 2011 r. Warszawa: Centralne Biuro Antykorupcyjne, pp. 15-20.

Corruption Perception Index. 2018. Available online: https://www.transparency.org/cpi2018 (accessed on 19 December 2019).

Czepil Bartosz. 2014. Korupcja a rozwój. Analiza funkcjonalnych aspektów korupcji. Prakseologia: 155, $295-324$.

Dąbrowska-Mikuta Izabela. 2013. Przyczyny i metody zwalczania zjawiska korupcji w samorządach lokalnych. Studia Ekonomiczne Regionu Łódzkiego: 11, 71-81.

De Maria William. 2008. Measurements and markets: deconstructing the corruption index. International Journal of Public Sector Management: 21 (7), 777-797. https://doi.org/10.1108/09513550810904569.

Denisova-Schmidt Elena, Prytula Yaroslav. 2018. Business corruption in Ukraine: A way to get things done? Business Horizons: 61, 867-879.

Department for International Development. 2015. Why corruption matters: understanding causes, effects and how to address them. Evidence paper on corruption. Available online: https://assets.publishing.service.gov.uk/government/uploads/system/uploads/attachment_data/file/406346/ corruption-evidence-paper-why-corruption-matters.pdf (accessed on 18 December 2019).

Fleszar Dorota. 2014. Z problematyki korupcji w administracji publicznej. Available online: https://sbc.org.pl/Content/134307/Fleszer.pdf (accessed on 18 December 2019).

Hołyst Brunon. 2014. Korupcja jako plaga społeczna XXI wieku. Przeglad Antykorupcyjny: 1 (1), 24-41.

Hussein Alina. 2017. Bezpieczeństwo antykorupcyjne dla rozwoju. Annales Universitatis Mariae Curie-Skłodowska: 51 (6), 117-127. http://dx.doi.org/10.17951/h.2017.51.6.117.

Jak zwalczać korupcję? Zasady tworzenia i wdrażania strategii antykorupcyjnych dla Polski. 2010. Warszawa: Wydaw. Fundacja Batorego, p. 18-19.

Jakubowski Roman. 2016. Cechy charakterystyczne korupcji i sposoby jej zapobiegania w administracji. In Korupcja w administracji. Katowice: Wydaw. Fundacji Akademickiej IPSO ORDO, pp. 21-42.

Lampart Daniel. 2015. Skuteczność zwalczania korupcji w Polsce. Obronność-Zeszyty Naukowe Wydziatu Zarzązania i Dowodzenia Akademii Obrony Narodowej: 3, 81-92.

Makowski Grzegorz. 2012. Społeczny wymiar korupcji. In Mapa korupcji. Stan przedsiębiorczości korupcyjnej w Polsce w 2011 r. Warszawa: Centralne Biuro Antykorupcyjne, pp. 15-20.

Sikorski Tomasz. 2008. Ukraina - „Dziki Wschód” dla przedsiębiorców. Available online: https://www.bankier.pl/wiadomosc/Ukraina-Dziki-Wschod-dla-przedsiebiorcow-1722578.html (accessed on 10 December 2019).

Stodolak Sebastian. 2018. Gospodarkę ukraińską dusi korupcja. Available online: https://www.obserwatorfinansowy.pl/tematyka/makroekonomia/gospodarke-ukrainska-dusi-korupcja (accessed on 15 December 2019).

Sumah Stefan. 2018. Corruption, Causes and Consequences. Available online: https://www.intechopen.com/books/trade-and-global-market/corruption-causes-and-consequences (accessed on 29 January 2020).

Szwejkowski Łukasz. 2013. Korupcja. Wybrane zagadnienia. Legionowo: Centrum Szkolenia Policji.

Transparency International. 2018. Corruption Perceptions Index 2018. Available online: https://www.transparency.org/cpi2018 (accessed on 15 December 2019).

Turska-Kawa Agnieszka. 2015. Psychologiczne determinanty korupcji politycznej. In Postawy wobec korupcji w samorzadzie terytorialnym. Raport z badań w województwie ślaskim. Sławków: Wydaw. Fundacji Akademickiej IPSO ORDO, s. 31-46.

Walczak Waldemar. 2016. Źródła zachowań o charakterze korupcyjnym w praktyce zarządzania, In Korupcja w administracji. Katowice: Wydaw. Fundacji Akademickiej IPSO ORDO, pp. 63-88.

Why corruption matters: understanding causes, effects and how to address them. 2015. Evidence paper on corruption. Department for International Development, UK. Available online: https://assets.publishing.service.gov.uk/government/uploads/system/uploads/attachment_data/file/406346/ corruption-evidence-paper-why-corruption-matters.pdf (accessed on 19 December 2019).

WJP Rule of Law Index 2019. Available online: https://worldjusticeproject.org/our-work/research-and-data/wjprule-law-index-2019 (accessed on 29 January 2020). 